\title{
Immature Seedling Growth of Two North American Native Perennial Bunchgrasses and the Invasive Grass Bromus tectorum
}

\author{
Jayanti Ray-Mukherjee, ${ }^{1}$ Thomas A. Jones, ${ }^{2}$ Peter B. Adler, ${ }^{3}$ and Thomas A. Monaco ${ }^{4}$
}

Authors are ${ }^{1}$ Postdoctoral Fellow, Florida International University, Miami, FL 33199, USA; ${ }^{2}$ Research Ecologist, USDA-ARS Forage and Range Research Laboratory, Utah State University, Logan, UT 84322-4820, USA; ${ }^{3}$ Assistant Professor, Department of Wildland Resources and the Ecology Center, Utah State University, Logan, UT 84322-4820, USA; and ${ }^{4}$ Research Ecologist, USDA-ARS Forage and Range Research Laboratory, Utah State University, Logan, UT 84322-6300, USA.

\begin{abstract}
Pseudoroegneria spicata (Pursh) A. Löve and Elymus wawawaiensis J. Carlson \& Barkworth are two native perennial grasses widely used for restoration in the Intermountain West. However, the rapid establishment and spread of Bromus tectorum L., an invasive annual grass, has led to a decline in the abundance of native perennial grasses. Proliferation of B. tectorum has been attributed to its early germination, superior cold-temperature growth, profuse root production, and high specific leaf area (SLA). To enhance restoration success, we compared B. tectorum to commercially available plant materials of two perennial rangeland bunchgrasses, P. spicata (cv. Whitmar, cv. Goldar, and Anatone Germplasm) and E. wawawaiensis (cv. Secar), for germination, seedling morphological traits, and growth rates at the immature seedling stage. We monitored germination and immature seedling growth in a growth chamber in two separate experiments, one under low $\left(5 / 10^{\circ} \mathrm{C}\right)$ and the other under high $\left(15 / 20^{\circ} \mathrm{C}\right)$ day/night temperatures. Compared to the average of the two perennials, B. tectorum was $93 \%(77 \%)$ greater at high (and low) temperature for root:shoot length ratio, but only 14\% (14\%) greater for root:shoot biomass ratio and $12 \%(19 \%)$ lower for SLA. This suggests that B. tectorum's substantial investment in surface area of roots, rather than in shoot length, root biomass, or leaf area, may be responsible for the annual's success at the early seedling stage. Compared to E. wawawaiensis, $P$. spicata averaged $65 \%(41 \%)$ higher shoot biomass, 39\% (88\%) higher root biomass, and $70 \%(10 \%)$ higher absolute growth rate, but 25\% (15\%) lower SLA and 15\% (36\%) lower specific root length (SRL) at high (and low) temperatures, respectively. Although $P$. spicata's greater productivity may initially make for better seedling establishment than E. wawawaiensis, it may also prove disadvantageous in competitive or highly resource-limited environments where high SLA or SRL could be an advantage.
\end{abstract}

\section{Resumen}

Pseudoroegneria spicata (Pursh) A. Löve y Elymus wawawaiensis J. Carlson \& Barkworth son dos pastos perennes nativos ampliamente utilizados para la restauración de pastizales naturales de la región comprendida entre las Rocallosas y las Sierras Nevadas del Oeste de los Estados Unidos (Intermountain West). Sin embargo, el rápido establecimiento y dispersión de Bromus tectorum L., una planta invasora anual, ha ocasionado una disminución en la abundancia de pastos perennes nativos. La proliferación de $B$. tectorum ha sido atribuida a su germinación temprana, su habilidad superior de crecer en condiciones de bajas temperaturas, su elevada producción radicular, y una elevada área foliar específica (AFE). Con la finalidad de mejorar el éxito de los proyectos de restauración, comparamos la germinación, los atributos morfológicos de las plántulas, y las tasas de crecimiento en los estadios previos a la madurez de las plántulas de B. tectorum y germoplasma disponible comercialmente de dos pastos cespitosos perennes, P. spicata (cv. Whitmar, cv. Goldar, y Anatone Germplasm) y E. wawawaiensis (cv. Secar). Monitoreamos la germinación y el crecimiento de plántulas durante los estadios previos a la madurez en una cámara de crecimiento en dos experimentos diferentes, uno en condiciones de baja $\left(5 / 10^{\circ} \mathrm{C}\right)$ y otro en condiciones de alta $\left(15 / 20^{\circ} \mathrm{C}\right)$ temperatura diurna/nocturna. Comparado con el promedio de ambas especies perennes, B. tectorum fue $93 \%(77 \%)$ superior en condiciones de alta (y baja) temperatura en la proporción del largo de raíz:tallo, pero solamente $14 \%(14 \%)$ mayor en la proporción de biomasa raíz:tallo y $12 \%(19 \%)$ más bajo en AFE. Esto sugiere que el éxito de esta especie anual durante los estadios tempranos de la plántula podría deberse a la inversión sustantiva en el área de superficie de raíces, en vez de invertir en largo de tallos, biomasa radicular, o área foliar. Comparado con E. wawawaiensis, $P$. spicata tuvo una biomasa de tallos $65 \%$ $(41 \%)$ más elevada, una biomasa radicular 39\% (88\%) más elevada y una tasa absoluta de crecimiento $70 \%(10 \%)$ más elevada, pero un AFE 25\% (15\%) inferior y una longitud específica de raíces (LER) 15\% (36\%) inferior bajo temperaturas altas (y bajas), respectivamente. Si bien la productividad superior de P. spicata podría inicialmente producir mejor establecimiento de

This research has been partially funded by the Great Basin Native Plant Selection and Increase Project, and we gratefully acknowledge this contribution by the Bureau of Land Management and the U.S. Forest Service Rocky Mountain Research Station.

Mention of a proprietary product does not constitute a guarantee of warranty of the product by USDA, Utah State University, or the authors and does not imply its approval to the exclusion of the other products that also may be suitable.

At the time of research, Ray-Mukherjee was a research assistant, Department of Wildland Resources and the Ecology Center, and research geneticist, USDA-ARS Forage and Range Research Laboratory, both at Utah State University, Logan, UT 84322, USA.

Correspondence: Jayanti Ray-Mukherjee, Dept of Wildland Resources, Utah State University, Logan, UT 84321, USA. Email: plants@scientist.com

Manuscript received 26 June 2010; manuscript accepted 22 March 2011. 
plántulas comparado con E. wawawaiensis, podría también estar en desventaja en situaciones de alta competencia o en ambientes con alta limitación de recursos en los que un elevado AFE o LER podrían ser ventajosos.

Key Words: absolute growth rate, bluebunch wheatgrass, relative growth rate, Snake River wheatgrass, specific leaf area, specific root length

\section{INTRODUCTION}

Past grazing practices, invasion by flammable weeds, and resultant increased fire frequency have contributed to declines in the abundance of perennial bunchgrasses, such as Pseudoroegneria spicata (Pursh.) A. Löve, on the rangelands of North America's Intermountain West (Daubenmire 1942; Young and Allen 1997; Whisenant 1999). Consequently, this $C_{3}$ species is widely used for restoration applications in the region (Monsen et al. 2004). Prior to 1986, another $C_{3}$ perennial Triticeae bunchgrass, Elymus wawawaiensis J. Carlson \& Barkworth, was taxonomically confused with $P$. spicata, owing to their superficial morphological resemblance (Carlson and Barkworth 1997). Since the commercial release of "Secar" E. wawawaiensis in 1980, this cultivar has become widely and successfully used as a restoration surrogate for P. spicata (Jones 2003). However, the realization that Secar is not P. spicata has made its use somewhat controversial. In addition, the natural distribution of E. wawawaiensis is mostly limited to eastern Oregon, eastern Washington, and northern and central Idaho (Carlson and Barkworth 1997), while most restoration sites where E. wawawaiensis is used fall outside of this area. Nevertheless, Secar E. wawawaiensis continues to be widely used in the Intermountain West (Young and Allen 1997; Monsen et al. 2004).

When present, invasive annual grasses, particularly Bromus tectorum L., threaten the integrity of sagebrush steppe rangelands (Jones and Monaco 2009) by limiting native grass seedling establishment (Harris and Wilson 1970; Young and Allen 1997) and replacing native vegetation (Sperry et al. 2006). Invasion by $B$. tectorum greatly increases fire frequency (Brooks et al. 2004), consequently damaging native vegetation (Whisenant 1990) and possibly modifying the soil environment in a way that reinforces its dominance (Saetre and Stark 2005; Norton et al. 2007). B. tectorum currently dominates large areas in western North America, and additional areas are at risk of invasion (Bradley and Mustard 2006; Jones and Monaco 2009).

The rapid establishment and spread of B. tectorum have been attributed to its superior germination, growth, and fitness. For example, it has the ability to germinate in fall, putting springgerminating perennial seedlings at a competitive disadvantage (Hardegree et al. 2010), and to germinate earlier in the spring than perennial grasses (Harris 1967; Harris and Wilson 1970; Harris 1977; Hardegree et al. 2010). In addition, B. tectorum grows vigorously above (Svejcar 1990) and below ground (Harris and Wilson 1970; Harris 1977; Young and Allen 1997; Arredondo et al. 1998) when temperatures are cold and soil moisture is least limiting (Bradford and Lauenroth 2006). This annual grass also produces large quantities of seeds in summer (Svejcar 1990; Young and Allen 1997; Sperry et al. 2006).

The competitive ability of B. tectorum has been attributed to functional traits such as high relative growth rate (RGR) (Arredondo et al. 1998), high specific leaf area (SLA) (Svejcar
1990), and high specific root length (SRL) (Svejcar 1990). The high RGR of invasive species is thought to be a major factor contributing to their invasive ability (Grotkopp et al. 2002; James and Drenovsky 2007). Annuals are known to have higher RGR than perennials (Poorter and Garnier 2007), and high RGR often reflects high resource-uptake rates exhibited by invasive species (Grotkopp et al. 2002). Specific leaf area is generally considered to be the best predictor for RGR (Poorter and Garnier 2007), and high SRL is often associated with rapid extraction of water and nutrients (Eissenstat 1991; Ryser 2006), as well as high SLA and RGR (Poorter and Garnier 2007). Studies have shown that B. tectorum's high SRL enables acquisition and utilization of early-season resources that typically diminish over the course of the season (Svejcar 1990; Ryser 2006). However, these studies compare established seedlings or mature plants, and functional-trait expression of germinating seedlings remains mostly unexplored (Jones et al. 2010).

Successful establishment of native grasses is often the limiting factor in sagebrush steppe restoration (Whisenant 1999; Monsen et al. 2004). A better understanding of growth and development of germinating perennial grass seedlings may lead to restoration plant materials with more successful establishment, particularly under cold-temperature conditions. Germination attributes, morphological traits, and growth rates are important factors that contribute to plant establishment (Monsen et al. 2004), especially under low spring temperatures. In this study our objectives were the following: 1) to identify immature seedling traits that may explain B. tectorum's early life-stage advantage relative to two perennial grasses $(P$. spicata, E. wawawaiensis) native to the sagebrush steppe; 2) to determine which commercially available native plant materials of these two native bunchgrasses display the best immature seedling-growth characteristics; and 3) to identify perennial-grass seedling traits associated with high productivity and superior growth rate. To this end we compared three commercially available P. spicata populations ["Whitmar" (released in 1946), "Goldar" (1989), and Anatone Germplasm (2003)], "Secar" (1980) E. wawawaiensis, and B. tectorum for germination, seedling morphological traits, and seedling growth under favorable (high temperature) and unfavorable (low temperature) conditions. In addition to days to germination, days to shoot initiation, shoot and root biomass, absolute growth rate (AGR), and RGR, we examined seedling morphological growth traits such as shoot and root length, SLA, SRL, root-to-shoot $(\mathrm{R}: \mathrm{S})$ biomass ratio, and $\mathrm{R}: \mathrm{S}$ length ratio.

We predicted that B. tectorum would germinate sooner, produce greater shoot and root biomass, and produce greater shoot and root length, as well as display higher R:S biomass ratio, R:S length ratio, SLA, and SRL than $P$. spicata and E. wawawaiensis, particularly at low temperature. We also predicted that $B$. tectorum would have the highest seedling RGR and that perennial plant materials with levels of trait expression most similar to B. tectorum would also have high 
seedling RGR. Based on previous findings (Gibbs et al. 1991; Kitchen and Monsen 1994), we also anticipated that the two native perennial grasses, once erroneously regarded as the same species, would display similar seedling biomass and growth characteristics. Finally, we predicted that the more recently released P. spicata plant materials, Goldar and particularly Anatone Germplasm, would display superior seedling growth characteristics relative to Whitmar, the first released P. spicata plant material.

\section{MATERIALS AND METHODS}

We employed three released populations of $P$. spicata (Goldar, Whitmar, and Anatone Germplasm), Secar E. wawawaiensis, and B. tectorum in this study. Seeds of all four perennial populations were produced in a common environment at Utah State University's Evans Farm at Millville, Utah, to avoid bias from confounded maternal effects resulting from multiple seed-production environments. While all seeds were produced in the same field, individual seed-production plots were established perpendicular to the prevailing wind and isolated by distance to minimize cross-pollination between plots. Seeds were harvested in 2007 , cleaned, and refrigerated $\left(5^{\circ} \mathrm{C}\right)$ until experimental use. Bromus tectorum seeds were harvested in 2005 from multiple locations in Idaho, USA, bulked, cleaned, and refrigerated until experimental use. Simultaneously, we conducted a laboratory germination trial with seeds collected from these sources with approximately $90-94 \%$ germination success of all seed sources.

We conducted two separate growth-chamber (Percival Scientific, Perry, IA) experiments under two contrasting temperature regimes. Both temperature regimes featured 12-h days and nights, and temperatures were recorded using data loggers (Watchdog, Spectrum Technologies, Plainfield, IL). Actual day/night temperatures were $20 \pm 1.25^{\circ} \mathrm{C} / 15 \pm 2.16^{\circ} \mathrm{C}$ for the high-temperature regime and $10 \pm 0.33^{\circ} \mathrm{C} / 5 \pm 0.28^{\circ} \mathrm{C}$ for the low-temperature regime. Light intensity was calculated (average 191.4 $\pm 9 \mu \mathrm{moles} \cdot \mathrm{m}^{2} \cdot \mathrm{s}^{-1}$ across temperatures) using a LI COR Model LI-185B photometer with a LI-190SB quantum sensor (LI-COR Biosciences, Lincoln, NE).

A total of 1000 seeds across two temperature regimes and three species, including the three P. spicata populations, were arranged in a completely randomized design. Four seeds (subsamples) were placed in a single germination pouch (CYG seed germination pouch, Mega International, St. Paul, $\mathrm{MN}$ ), which is a folded plastic sheet enclosing a blotter paper. Twenty-five pouches (replicates) of each population were used in each growth chamber, which were nested within populations. Thus, we evaluated a total of 100 seeds of each population at each temperature.

We sprayed blotter papers to saturation with distilled water, and pouches were rewatered as necessary throughout the experiment to maintain desirable moisture conditions. The study was initiated on 12 August 2008. Each seed was monitored daily, and the dates of first appearance of radicle (approximately $1 \mathrm{~mm}$ ) and coleoptile $(1 \mathrm{~mm})$ were recorded as germination and shoot initiation, respectively. Germination pouches were randomly rotated each week within the growth chambers.
Seedlings from 12 replicates were destructively harvested $8 \mathrm{~d}$ following initial watering for the high-temperature experiment and $16 \mathrm{~d}$ for the low-temperature experiment. The remaining 13 replicates were harvested $7 \mathrm{~d}$ following the first harvest for both temperatures. The low-temperature harvest was delayed relative to high temperature to allow seedlings to be sufficiently sizeable for measuring seedling traits. At harvest, a digital image of each seedling was obtained with a flatbed scanner (300 dpi). Images were analyzed with WinRHIZO Pro Version 2005b (Reagent Instrument, Québec City, Canada) to determine leaf area, leaf length, and root length. Subsequently, shoots and roots were separated and oven dried $\left(60^{\circ} \mathrm{C}\right.$ for $\left.48 \mathrm{~h}\right)$ to determine dry mass. For each temperature, scanned images were analyzed for shoot and root length, leaf area, SLA $\left(\mathrm{cm}^{2} \cdot \mathrm{mg}^{-1}\right)$, and SRL $\left(\mathrm{cm} \cdot \mathrm{mg}^{-1}\right)$. Absolute growth rate (AGR) was calculated as $\mathrm{AGR}=\left[\mu\left(W_{2}\right)-\mu\left(W_{1}\right)\right] /\left(t_{2}-t_{1}\right)$, and relative growth rate was calculated as $\mathrm{RGR}=$ $\left[\mu\left(\ln W_{2}\right)-\mu\left(\ln W_{1}\right)\right] /\left(t_{2}-t_{1}\right)$, where and $W_{1}$ and $W_{2}$ were the dry masses (shoot+root) from the first and second harvests, respectively, and $\mu$ was the mean biomass for the indicated harvest.

Data were analyzed using SAS 9.1.3 (SAS 2003), and data were transformed as necessary to meet normality assumptions (Table 1). Data were analyzed separately for each temperature, and nontransformed means were used for graphical presentation. Using the formulas mentioned above and the data collected at the two harvests, we used ESTIMATE statements in PROC MIXED in SAS to calculate means and standard errors for AGR and RGR for species and populations. From these values, confidence intervals were calculated to separate individual means.

We used data from all replicates to calculate days to germination and days to shoot initiation, while the remaining traits were determined only from replicates assigned to the second harvest. For mean comparisons, one-way analysis of variance (ANOVA) was performed for each variable separately with PROC MIXED. We used a comparison-wise error term rather than an experiment-wise error term because we wished to perform separate examinations for each of the functional traits. We set the minimum critical alpha value for tests of significance at 0.05 .

\section{RESULTS}

Bromus tectorum germinated (initiated roots) approximately $1.5 \mathrm{~d}$ earlier than P. spicata and Secar E. wawawaiensis at high temperature $(P<0.0001)$, and approximately $3 \mathrm{~d}$ earlier at low temperature $(P<0.0001)$ (Table $1 ;$ Fig. 1a). The two native perennial species did not differ for days to germination at either temperature $(P>0.05)$ (Table 1). Bromus tectorum initiated shoots (coleoptiles) approximately $0.9 \mathrm{~d}$ earlier than $P$. spicata and $1.1 \mathrm{~d}$ earlier than Secar E. wawawaiensis at high temperature $(P<0.0001)$, while B. tectorum initiated shoots 1.0, 1.3, 2.6, and $1.9 \mathrm{~d}$ earlier than Whitmar, Anatone, Goldar, and E. wawawaiensis, respectively, at low temperature $(P<0.0001)$ (Table 1; Fig. 1b).

At high temperature, P. spicata and B. tectorum produced $65 \%$ and $29 \%$ greater shoot biomass than E. wawawaiensis, respectively $(P<0.0001)$ (Table 1 ; Fig. 2a). Meanwhile, at low 
Table 1. Analysis of variance ( $F$ values) for 10 seedling traits of three populations of Pseudoroegneria spicata, Secar Elymus wawawaiensis, and Bromus tectorum at high temperature and low temperature.

\begin{tabular}{|c|c|c|c|c|}
\hline Traits & $\mathrm{df}$ & Transformations & Species $^{1}$ & Among P. spicata populations ${ }^{1}$ \\
\hline & \multicolumn{4}{|c|}{ 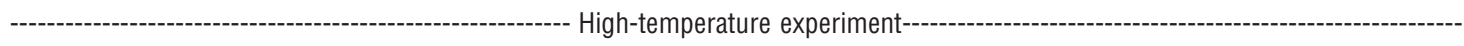 } \\
\hline Days to root initiation & 2,120 & Fourth root & $270.64^{* * *}$ & 2.30 \\
\hline Days to shoot initiation & 2,120 & $\log$ & $66.45^{\star \star \star}$ & 0.89 \\
\hline Shoot (S) biomass (mg) & 2,60 & Cube root & $37.82^{\star \star \star}$ & $6.27^{\star *}$ \\
\hline Root (R) biomass (mg) & 2,60 & - & $7.57^{\star}$ & 2.82 \\
\hline $\mathrm{R}: \mathrm{S}$ biomass ratio & 2,60 & - & $7.45^{\star *}$ & $4.47^{\star}$ \\
\hline Shoot length (mm) & 2,60 & - & $85.22^{\star \star \star}$ & $12.49^{\star \star \star}$ \\
\hline Root length (mm) & 2,60 & - & $14.27^{\star \star \star}$ & $4.11^{*}$ \\
\hline $\mathrm{R}: \mathrm{S}$ length ratio & 2,60 & Square root & $95.10^{\star * *}$ & 3.74 \\
\hline $\mathrm{SLA}\left(\mathrm{cm}^{2} \cdot \mathrm{mg}^{-1}\right)$ & 2,60 & Log & $20.69^{* * *}$ & 2.31 \\
\hline $\mathrm{SRL}\left(\mathrm{cm} \cdot \mathrm{mg}^{-1}\right)$ & 2,60 & Log & $3.19^{*}$ & 0.62 \\
\hline Days to root initiation & 2,120 & Reciprocal square root & $135.26^{* * *}$ & 1.83 \\
\hline Days to shoot initiation & 2,120 & Cube root & $61.51^{* * *}$ & $31.37^{* \star *}$ \\
\hline Shoot (S) biomass (mg) & 2,55 & Cube root & $7.50^{\star *}$ & 0.05 \\
\hline Root $(\mathrm{R})$ biomass $(\mathrm{mg})$ & 2,55 & Square root & $13.89^{* * *}$ & 1.38 \\
\hline $\mathrm{R}: \mathrm{S}$ biomass ratio & 2,55 & Square root & $9.24^{\star *}$ & $5.28^{\star \star}$ \\
\hline Shoot length (mm) & 2,55 & - & $39.97^{\star \star *}$ & 0.43 \\
\hline Root length (mm) & 2,55 & - & $7.97^{\star \star}$ & $5.83^{\star *}$ \\
\hline $\mathrm{R}: \mathrm{S}$ length ratio & 2,55 & Cube root & $62.71^{* * *}$ & 2.83 \\
\hline $\mathrm{SLA}\left(\mathrm{cm}^{2} \cdot \mathrm{mg}^{-1}\right)$ & 2,55 & Log & $14.99^{\star * *}$ & 0.26 \\
\hline $\mathrm{SRL}\left(\mathrm{cm} \cdot \mathrm{mg}^{-1}\right)$ & 2,55 & Log & $8.94^{* * *}$ & 1.10 \\
\hline
\end{tabular}

$1^{*} P<0.05,{ }^{* *} P<0.01,{ }^{* * *} P<0.0001$.

temperature, P. spicata and B. tectorum produced $41 \%$ and $30 \%$ greater shoot biomass than E. wawawaiensis, respectively $(P<0.05)$ (Table 1; Fig. 2a). Among P. spicata populations, shoot biomass of Goldar and Anatone was $24 \%$ and $16 \%$ greater, respectively, than Whitmar at high temperature $(P<0.05)$, while at low temperature the populations displayed similar shoot biomass $(P>0.05)$ (Table 1; Fig. 2a).
Under both temperatures, species differed for root biomass, while $P$. spicata populations did not $(P>0.05)$ (Table 1; Fig. 2b). At high temperature, root biomass of E. wawawaiensis was $28 \%$ and $26 \%$ lower than P. spicata and B. tectorum, respectively $(P<0.05)$, while at low temperature, these differences, $46 \%$ and $40 \%$, were much greater $(P<0.0001)$ (Table 1; Fig. 2b). Bromus tectorum and Whitmar displayed

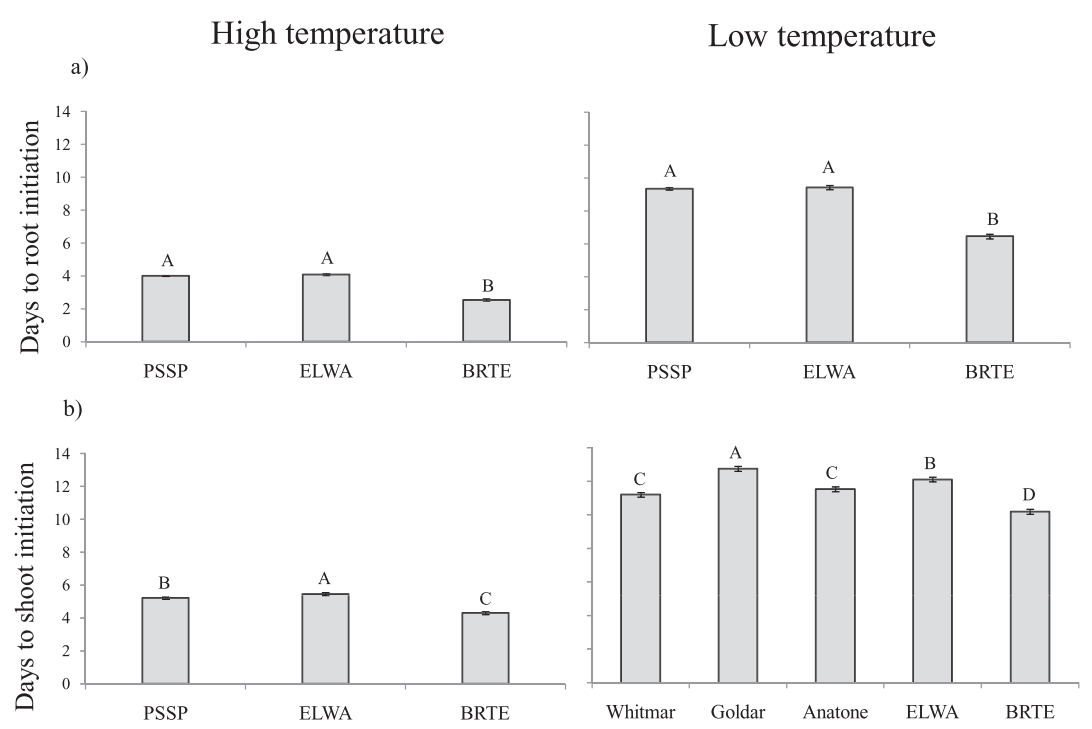

Figure 1. Means and standard errors at high (left panels) and low (right panels) temperatures for (a) days to root initiation and (b) days to shoot initiation for three Pseudoroegneria spicata (PSSP) populations, or their mean when they were not significantly different $(P>0.05)$, Secar Elymus wawawaiensis (ELWA), and Bromus tectorum (BRTE). Different letters represent significant $(P<0.05)$ differences among populations or species within each temperature. 


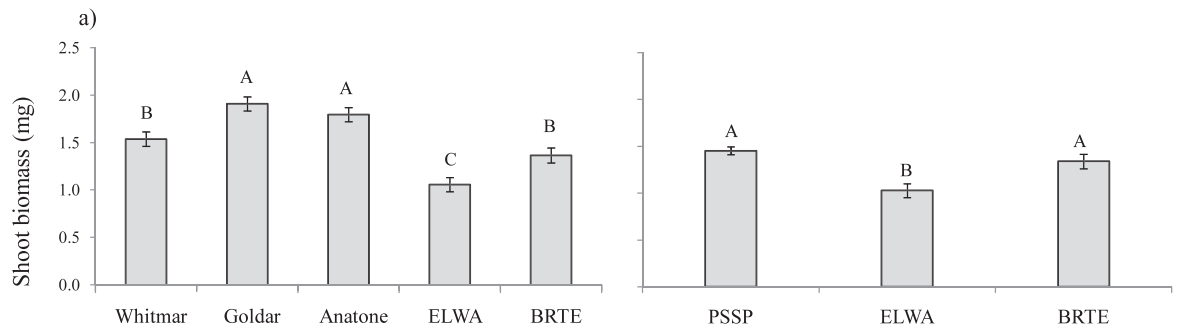

b)
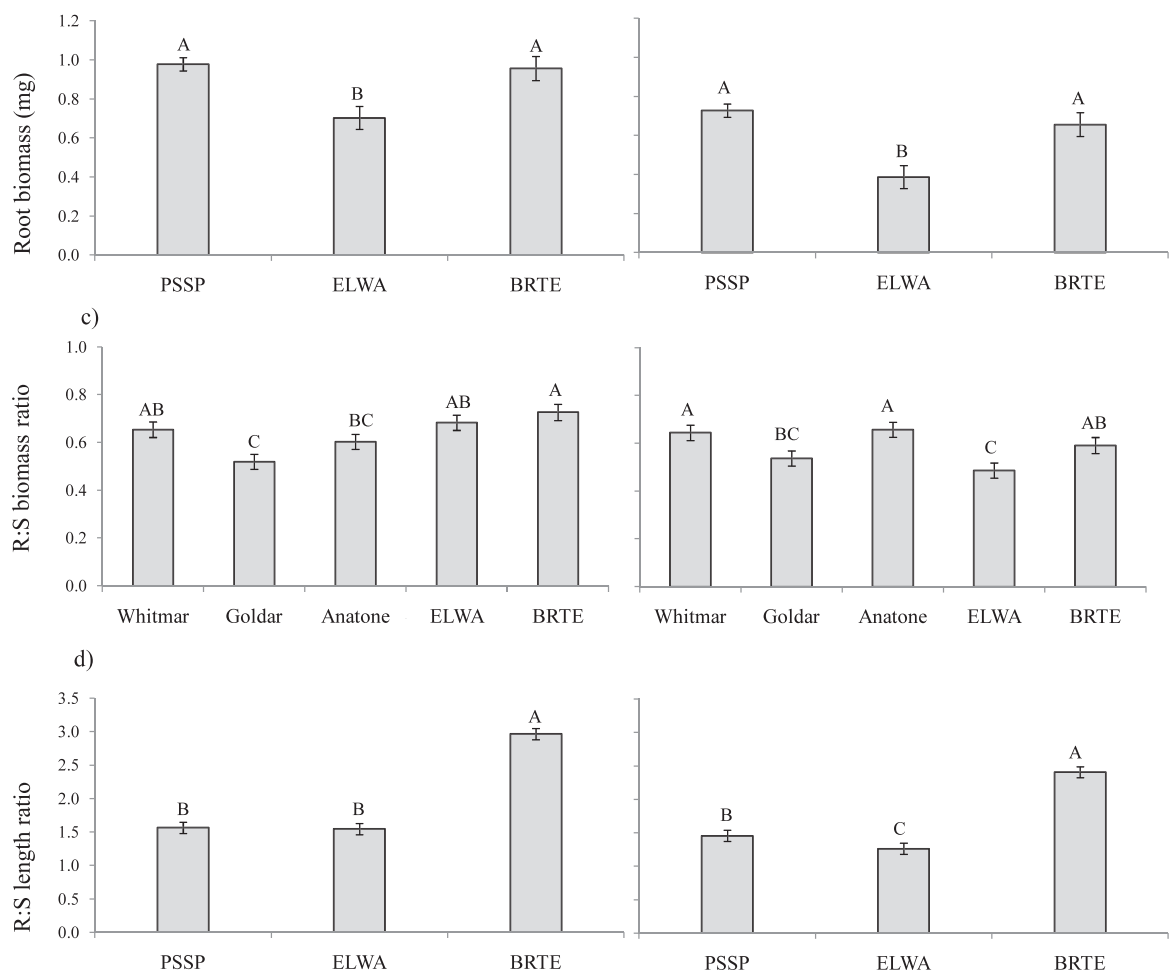

Figure 2. Means and standard errors at high (left panels) and low (right panels) temperatures for (a) shoot biomass, (b) root biomass, (c) root:shoot biomass ratio (R:S biomass ratio, and (d) root:shoot length ratio (R:S length ratio) for three Pseudoroegneria spicata (PSSP) populations, or their mean when they were not significantly different $(P>0.05)$, Secar Elymus wawawaiensis (ELWA), and Bromus tectorum (BRTE). Different letters represent significant $(P<0.05)$ differences between populations or species within each temperature.

high R:S biomass ratios at both temperatures, while Goldar was low at both temperatures (Fig. 2c). Anatone exhibited a high R:S biomass ratio at low temperature and a low ratio at high temperature, while Secar E. wawawaiensis displayed the reverse (Fig. 2c). Great differences among species were found for R:S length ratio at both temperatures (Table 1). At high temperature, the invasive B. tectorum displayed $91 \%$ greater R:S length ratio $(P<0.0001)$ than $P$. spicata and $E$. wawawaiensis, which were similar $(P>0.05)$ (Fig. 2d). At low temperature, R:S length ratio of Bromus tectorum was $65 \%$ greater than P. spicata and $90 \%$ greater than E. wawawaiensis, and $P$. spicata's R:S length ratio was $15 \%$ greater than that of E. wawawaiensis $(P<0.0001)$ (Fig. $2 \mathrm{~d})$. The three $P$. spicata populations were similar for R:S length ratio under both temperature regimes $(P>0.05)$ (Table 1$)$.

No differences were found among $P$. spicata populations for SLA or SRL at either temperature (Table 1). At high temperature, E. wawawaiensis produced $31 \%$ more SLA than the mean $P$. spicata and B. tectorum $(P<0.0001)$, which were similar $(P>0.05)$ (Table 1; Fig. 3a). At low temperature, SLA of E. wawawaiensis was $18 \%$ greater than P. spicata and $34 \%$ greater than $B$. tectorum $(P<0.0001)$ (Fig. 3a). At high temperature, Elymus wawawaiensis produced the highest SRL, with $P$. spicata being lowest $(P<0.05)$ and B. tectorum being intermediate and not different from the other species $(P>0.05)$ (Table 1; Fig. 3b). At low temperature, E. wawawaiensis was again highest for SRL, this time being $53 \%$ greater than the mean of $P$. spicata and B. tectorum, which were similar $(P>0.05)$ (Fig. 3b).

On average, $P$. spicata had the highest AGR under both temperature regimes (Fig. 4a), 45\% (71\%) and 66\% (35\%) greater than E. wawawaiensis and B. tectorum, respectively, at high (and low) temperature. Elymus wawawaiensis and $B$. tectorum were similar $(P>0.05)$ for AGR at high temperature, but $B$. tectorum was higher than E. wawawaiensis at low temperature. Among P. spicata populations, Anatone and Goldar exceeded Whitmar for AGR at high temperature $(P<0.05)$, while at low temperature, the $P$. spicata populations 
a)
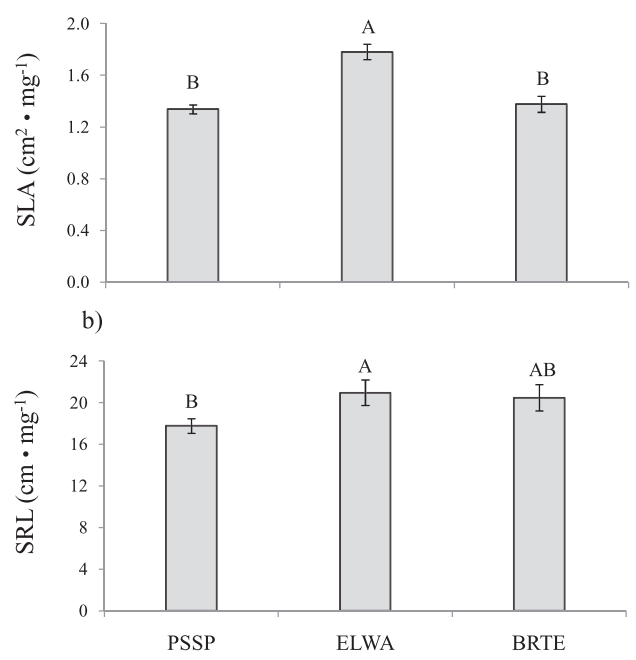
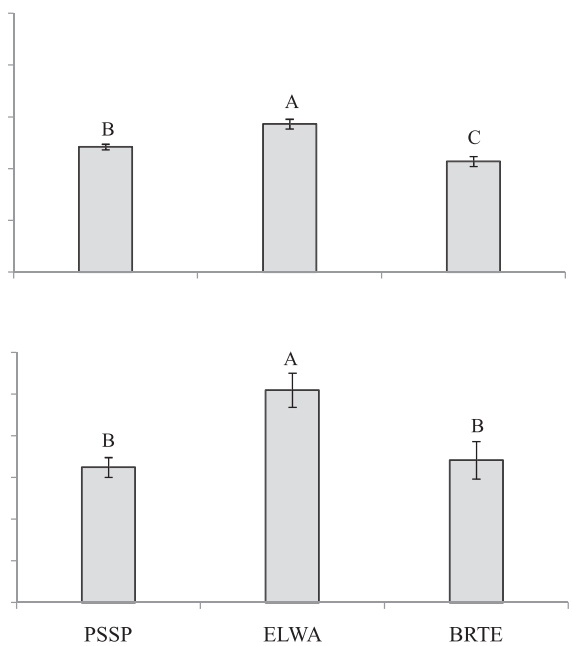

Figure 3. Means and standard errors at high (left panels) and low (right panels) temperatures for (a) specific leaf area (SLA) and (b) specific root length (SRL) for the mean of three not significantly different $(P>0.05)$ Pseudoroegneria spicata (PSSP) populations, Secar Elymus wawawaiensis (ELWA), and Bromus tectorum (BRTE). Different letters represent significant $(P<0.05)$ differences between species within each temperature.

were similar $(P>0.05)$. At high and low temperature, $B$. tectorum displayed $40 \%$ and $27 \%$ lower RGR $(P<0.0001)$, respectively, than the mean of the perennial species, which were similar $(P>0.05)$ (Fig. 4c). The three $P$. spicata populations did not differ $(P>0.05)$ in RGR for either temperature regime.

\section{DISCUSSION}

Our first objective was to identify seedling traits that are likely to contribute to B. tectorum's rapid establishment. Overall, the most striking difference displayed by B. tectorum compared to the native perennials was the former's exceptionally high R:S length ratio, which was evident at both temperatures. In addition, in accordance with our prediction, B. tectorum also produced high R:S biomass ratio under both temperature regimes. These data suggest that B. tectorum displays a strategy of emphasizing root biomass, and particularly root surface area, in young seedlings at the expense of photosynthetic shoot biomass and leaf area. In semiarid environments, this strategy may pay dividends as the season progresses and plant competition increases for declining soil moisture.

Consistent with our prediction, B. tectorum germinated and initiated shoots earlier than the perennials under both temperature regimes, and these differences were greater at cold temperature. Mean germination time is considered to be a

a)

High temperature

Low temperature
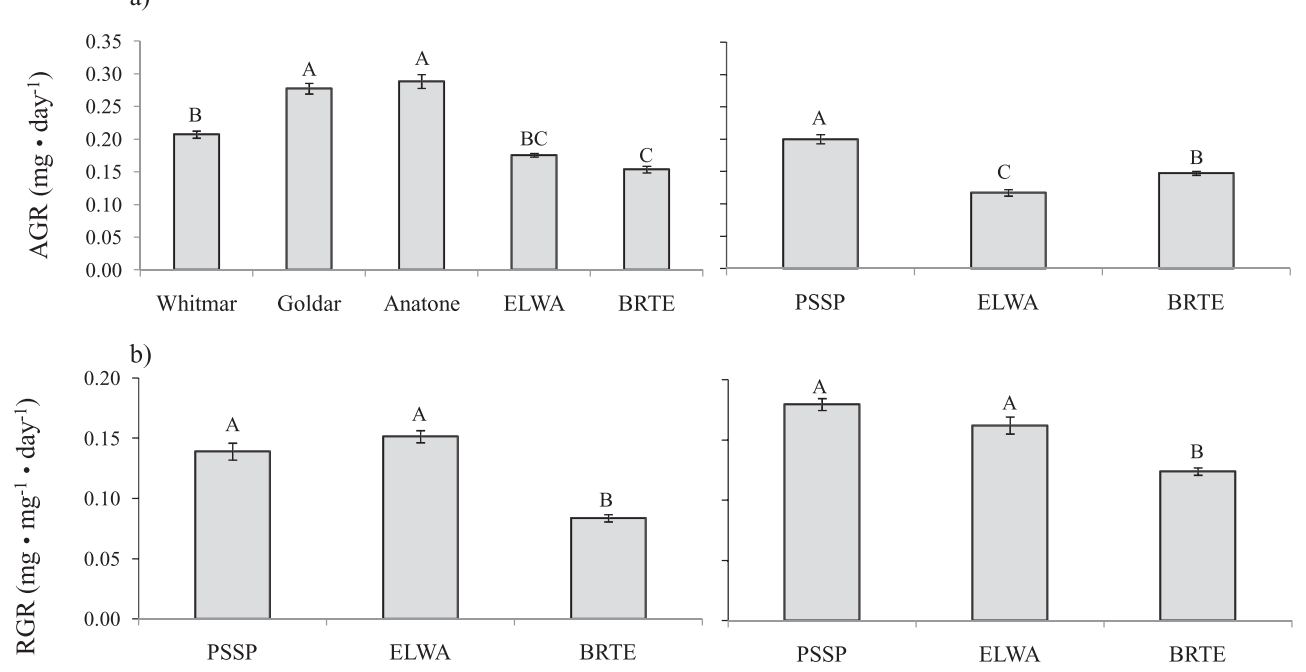

Figure 4. Means and standard errors at high (left panels) and low (right panels) temperatures for (a) absolute growth rate (AGR) and (b) relative growth rate (RGR) for three Pseudoroegneria spicata (PSSP) populations, or their mean when they were not significantly different $(P>0.05)$, Secar Elymus wawawaiensis (ELWA), and Bromus tectorum (BRTE). Different letters represent significant $(P<0.05)$ differences between populations or species within each temperature. 
highly phylogenetically conserved trait (Norden et al. 2009), and early germination may be associated with a species's invasive ability (Grotkopp et al. 2002). However, early germination of $B$. tectorum was not associated with high AGR or RGR at the early seedling stage, contrary to our expectation based on the literature (Aguirre and Johnson 1991; Grotkopp et al. 2002). This disparity in AGR may be attributed to the small seed mass $\left(2.63 \pm 0.05 \mathrm{mg} \cdot \mathrm{seed}^{-1}\right)$ of the annual compared to the perennials $\left(3.76 \pm 0.20 \mathrm{mg} \mathrm{seed}^{-1}\right)$. The substantially lower RGR of $B$. tectorum compared to that of both perennials is more surprising and was associated with its low SLA. Relative growth rate may change over time in a plant's life cycle (Hunt 1982), and typically RGR is highest $\left(\mathrm{RGR}_{\max }\right)$ during the first few days postgermination and then declines over time. A low RGR for B. tectorum and a high RGR for $P$. spicata could thus result from temporal differences in $\mathrm{RGR}_{\max }$ between species (Hunt 1982; Grotkopp et al. 2002). Because $B$. tectorum germinates in the fall, it may require seedling tissues that are well constructed (low SLA and SRL) to overwinter. At the same time, it is conceivable that $B$. tectorum may shift its growth strategy in spring to favor greater surface area that may fuel faster growth.

Our second objective was to compare the four commercially available perennial populations for immature seedling characteristics that may contribute to enhanced seedling growth. In contrast to our prediction, we found that $P$. spicata produced greater shoot biomass, root biomass, and shoot length than Secar E. wawawaiensis under both temperature regimes. On the other hand, SLA for Secar was consistently greater than that for P. spicata at both temperatures. In addition, Secar had 50\% greater SRL than P. spicata at low temperature. As shown in previous studies, high SLA, SRL, and RGR are properties of fast-growing species (Poorter and Garnier 2007). This suggests that, of the two native perennials, E. wawawaiensis may be better equipped, by virtue of its high SLA and SRL, to compensate for its low initial biomass as the growing season progresses (Zhang and Maun 1990). Consistent with our final prediction, the most recently released $P$. spicata population, Anatone, displayed superior seedling growth characteristics compared to the earliest-released Whitmar, particularly at high temperature.

Overall, our results suggest that E. wawawaiensis is more conservative in shoot and root biomass investment relative to surface-area investment (SLA and SRL) at the immatureseedling stage at both temperatures, while $P$. spicata exhibits the opposite trend. Differences in immature-seedling traits could be crucial for seedling establishment, particularly under the low temperatures of early spring, the time of year when soil moisture is most favorable for seedling growth on Intermountain rangelands. For example, low temperature reduced root biomass more for Secar E. wawawaiensis (45\%) than P. spicata $(26 \%)$, while low temperature reduced shoot biomass more for P. spicata $(33 \%)$ than for E. wawawaiensis $(22 \%)$. Together, these numbers resulted in a $28 \%$ reduction in R:S biomass ratio by low temperature for E. wawawaiensis, compared to only a $6 \%$ reduction for $P$. spicata. In contrast to root biomass, reductions in root length due to low temperature were similar in P. spicata (54\%) and E. wawawaiensis (58\%). This resulted in a $27 \%$ reduction in SRL from high to low temperature for $P$. spicata, compared to a $3 \%$ decline for E. wawawaiensis. On the other hand, SLA of $P$. spicata was reduced $28 \%$ from high to low temperature, while the reduction was $36 \%$ for $E$. wawawaiensis.

Our final objective was to identify traits associated with superior seedling growth. Our prediction that perennials most similar to B. tectorum would display the greatest RGR was based on the assumption that B. tectorum would feature the greatest RGR. However, our data did not support this assumption. Nevertheless, we were able to identify traits in the perennial species that are likely to contribute to superior seedling growth rate.

For AGR, P. spicata was clearly superior to E. wawawaiensis, which we attribute to its larger seed mass $\left(3.76 \mathrm{mg} \cdot \mathrm{seed}^{-1}\right)$ relative to E. wawawaiensis $\left(2.88 \mathrm{mg} \cdot \mathrm{seed}^{-1}\right)$. On the other hand, the two perennials were similar for RGR. Traits associated with high AGR in P. spicata were high length and biomass of shoots and roots, while traits that likely contributed to high RGR in E. wawawaiensis were high SLA and SRL. Specific leaf area and SRL are two traits closely associated with plant life history, and species with high SLA and SRL are associated with high competitive and invasive ability (Grotkopp et al. 2002) and resource-rich environments (Reich et al. 1998; Ryser 2006). Nevertheless, despite originating from a more arid locale than any of the three $P$. spicata populations, Secar E. wawawaiensis displayed very high SLA and SRL (Monsen et al. 2004). We believe that high SLA and SRL are two traits that may be crucial for future selection of perennial plant materials for restoration. High SLA may confer high growth rate, and high SRL may enable greater resource extraction (Svejcar 1990; Arredondo et al. 1998).

\section{IMPLICATIONS}

Our comparison at the immature seedling stage reveals two traits that may contribute to B. tectorum's successful establishment and great competitive ability: 1) rapid germination and 2) a high investment in root length relative to shoot length. While we predicted that perennial species that displayed trait levels most similar to $B$. tectorum would display greatest seedling growth, we found that $P$. spicata and E. wawawaiensis were quite similar for the two above-mentioned traits, particularly when compared to B. tectorum. In spite of this, inspection of other traits revealed fundamental differences that elucidate contrasting seedling-growth strategies for these two perennial grasses. While $P$. spicata's high AGR provides an advantage for initial seedling establishment, its relatively low SLA and its greater investments in biomass, despite a greater RGR ( $\mathrm{RGR}_{\max }$ ), may eventually limit its growth rate (Harris 1977; Reich et al. 1994) as resource availability declines. Secar E. wawawaiensis, on the other hand, displays greater aboveand below-ground surface area per unit biomass that likely contributes to biomass accumulation and competitive ability once established.

Bromus tectorum is an extremely effective competitor with perennial grasses, particularly under cold temperatures. Establishment of seeded perennial grasses could be improved if seedlings displayed improved cold-temperature growth in spring, making them more competitive with spring-germinating B. tectorum. Perennial grass materials that germinate earlier 
and display higher R:S length ratios, particularly under cold temperatures, are potentially more effective competitors with B. tectorum. While this research was conducted on bluebunch wheatgrass ( $P$. spicata) and Snake River wheatgrass (E. wawawaiensis), the results may provide clues for selecting for improved cold-temperature growth potential in other perennial grass species, such as sandberg bluegrass (Poa secunda J. Presl), big squirreltail (Elymus multisetus [J. G. Sm.] Burtt Davy), and bottlebrush squirreltail (E. elymoides [Raf.] Swezey).

\section{ACKNOWLEDGMENTS}

We thank Ronald J. Ryel and Christopher A. Call for their fruitful comments and intriguing discussions. We also thank Dale Nielson, Jenny Christiansen, Tren Hagman, and Phil Harrison for their technical help throughout the project and Susan Durham for her help with statistical analysis. We thank Josh Leffler for his useful comments prior to journal submission. We also thank the two anonymous reviewers, whose contributions improved our manuscript to a great extent.

\section{LITERATURE CITED}

Aguirre, L., And D. A. Johnson. 1991. Root morphological development in relation to shoot growth in seedlings of four range grasses. Journal of Range Management 44:341-346.

Arredondo, J. T., T. A. Jones, And D. A. Johnson. 1998. Seedling growth of Intermountain perennial and woody annual grasses. Journal of Range Management 54:584-589.

Bradford, J. B., and W. K. Lauenroth. 2006. Controls over invasion of Bromus tectorum: the importance of climate, disturbance, soil and seed availability. Journal of Vegetation Science 17:693-704.

Bradley, B. A., And J. F. Mustard. 2006. Characterizing the landscape dynamics of an invasive plant and risk of invasion using remote sensing. Ecological Applications 16:1132-1147.

Brooks, M. L., C. M. D’Antonio, D. M. Richardson, J. B. Grace, J. E. Keeley, J. M. Ditomaso, R. J. Hobbs, M. Pellant, and D. Pyke. 2004. Effect of invasive alien plants on fire regimes. Bioscience 54:677-688.

Carlson, J. R., and M. E. Barkworth. 1997. Elymus wawawaiensis: a species hitherto confused with Pseudoroegneria spicata (Triticeae, Poaceae). Phytologia 83:312-330.

DaubenmiRe, R. F. 1942. An ecological study of the vegetation of southeastern Washington and adjacent Idaho. Ecological Monographs 12:53-79.

EISSENSTAT, D. M. 1991. On the relationship between specific root length and the rate of root proliferation: a field study using citrus rootstocks. New Phytologist 118:63-68.

GibBS, J. L., G. Young, And J. R. CARLson. 1991. Registration of 'Goldar' bluebunch wheatgrass. Crop Science 31:1708.

Grotkopp, E., M. Rejmánek, AND T. L. Rost. 2002. Toward a causal explanation of plant invasiveness: seedling growth and life history strategies of 29 pine (Pinus) species. American Naturalist 159:396-419.

Hardegree, S. P., C. A. Moffet, B. A. Roundy, T. A. Jones, S. J. Novak, P. E. Clark, F. B. Pierson, and G. N. Flerchinger. 2010. A comparison of cumulativegermination response of cheatgrass (Bromus tectorum L.) and five perennial bunchgrass species to simulated field-temperature regimes. Environmental and Experimental Botany 69:320-327.

HarRIS, G. A. 1967. Some competitive relationships between Agropyron spicatum and Bromus tectorum. Ecological Monographs 37:89-111.

HARRIS, G. A. 1977. Root phenology as a factor of competition among grass seedlings. Journal of Range Management 30:172-177.
HarRis, G. A., And A. M. Wilson. 1970. Competition for moisture among seedlings of annual and perennial grasses as influenced by root elongation at low temperature. Ecology 51:530-534.

Hunt, R. 1982. Plant growth curves: the functional approach to plant growth analysis. London, UK: Edward Arnold. 248 p.

James, J. J., And R. E. Drenovsky. 2007. A basis of relative growth rate differences between native and invasive forb seedlings. Rangeland Ecology \& Management 60:395-400.

Jones, T. A. 2003. The Restoration Gene Pool concept: beyond the native vs. nonnative debate. Restoration Ecology 11:281-290.

Jones, T. A., And T. A. Monaco. 2009. A role for assisted evolution in designing native plant materials for domesticated landscapes. Frontiers of Ecology and the Environment 10:541-547.

Jones, T. A., T. A. Monaco, and J. J. James. 2010. Launching the counterattack: interdisciplinary deployment of functional traits to repair Intermountain rangelands damaged by annual grass invasion. Rangelands 32:38-42.

Kitchen, S. G., And S. B. Monsen. 1994. Germination rate and emergence success in bluebunch wheatgrass. Journal of Range Management 47:145-150.

Monsen, S. B., R. Stevens, and N. L. Shaw. 2004. Grasses. In: S. B. Monsen, R. Stevens, and N. L. Shaw [EDS.]. Restoring western ranges and wildlands. Vol. 2. Fort Collins, C0, USA: U.S. Forest Service, General Technical Report RMRS-GTR 136. $698 \mathrm{p}$.

Norden, N., M. I. Daws, C. Antoine, M. A. Gonzalez, N. C. Garwood, and J. Chave. 2009. The relationship between seed mass and mean time to germination for 1037 tree species across five tropical forests. Functional Ecology 23:203-210.

Norton, J. B., T. A. Monaco, and U. Norton. 2007. Mediterranean annual grasses in western North America: kids in a candy store. Plant and Soil 298:1-5.

Poorter, H., and E. Garnier. 2007. Ecological significance of inherent variation in relative growth rate and its components. In: F. I. Pugnaire and F. Valladares [eds.]. Functional Plant Ecology. Boca Raton, FL, USA: CRC Press. p. 67-100.

ReICH, P. B., J. OLEKSYN, AND M. J. TJoelKER. 1994. Seed mass effects on germination and growth of diverse European Scots pine populations. Canadian Journal of Forest Research 24:306-320.

Reich, P. B., M. G. Tuoelker, M. B. Walters, D. W. Vanderklein, and C. Buschena. 1998. Close association of RGR, leaf and root morphology, seed mass, and shade tolerance in seedlings of nice boreal tree species grown in high and low light. Functional Ecology 12:327-338.

RYSER, P. 2006. The mysterious root length. Plant and Soil 286:1-6.

Saetre, P., and J. M. Stakk. 2005. Microbial dynamics and carbon and nitrogen cycling following re-wetting of soils beneath two semi-arid plant species. Oecologia 142:247-260.

SAS [Computer Program]. 2003. Version 9.1.3. Cary, NC, USA: SAS Institute. 707 p.

SperRy, L. J., J. Belnap, and R. D. Evans. 2006. Bromus tectorum invasion alters nitrogen dynamics in an undisturbed grassland ecosystem. Ecology 87:603-615.

SVEJCAR, T. J. 1990. Root length, leaf area, and biomass of crested wheatgrass and cheatgrass seedlings. Journal of Range Management 43:446-448.

Whisenant, S. G. 1990. Changing fire frequencies on Idaho's Snake River Plains: ecological and management implications. In: E. D. McArthur, E. M. Romney, S. D. Smith, and P. T. Tueller [EDS.]. Proceedings-symposium on cheatgrass invasion, shrub die-off, and other aspects of shrub biology and management. 5-7 April 1989; Las Vegas, NV; General Technical Report INT276. Ogden, UT, USA: USDA Forest Service, Intermountain Research Station. p. 4-10.

Whisenant, S. G. 1999. Repairing damaged wildlands: a process-oriented, landscape-scale approach. Cambridge, UK: Cambridge University Press. 312 p.

Young, J. A., And Allen, F. L. 1997. Cheatgrass and range science: 1930-50. Journal of Range Management 50:530-535.

Zhang, J., And M. A. Maun. 1990. Effects of sand burial on seed germination, seedling emergence, survival, and growth of Agropyron psammophilum. Canadian Journal of Botany 68:304-310. 